\title{
Article \\ Knowledge, Prevalence and Factors Associated with Sexually Transmitted Diseases among Female Students of a Federal University in Southern Nigeria
}

\author{
Chimezie Nzoputam ${ }^{1,2, * \mathbb{D}}$, Vincent Yakubu Adam ${ }^{2,3}$ and $^{-}$Ogochukwu Nzoputam ${ }^{4}$ (D) \\ 1 Department of Medical Biochemistry, School of Basic Medical Sciences, University of Benin \\ Benin City 300001, Nigeria \\ 2 Department of Public Health, Center of Excellence in Reproductive Health Innovation, University of Benin, \\ Benin City 300001, Nigeria; vincent.adam@uniben.edu \\ 3 Department of Community Health, School of Medicine, University of Benin, Benin City 300001, Nigeria \\ 4 Department of Physiology, School of Basic Medical Sciences, University of Benin, Benin City 300001, Nigeria; \\ ogochukwu.nzoputam@gmail.com \\ * Correspondence: chimezie.nzoputam@gmail.com
}

Citation: Nzoputam, C.; Adam, V.Y.; Nzoputam, O. Knowledge, Prevalence and Factors Associated with Sexually Transmitted Diseases among Female Students of a Federal University in Southern Nigeria. Venereology 2022, 1, 81-97. https:// doi.org/10.3390/venereology1010006

Academic Editor: Sylvia Bruisten

Received: 8 January 2022

Accepted: 7 February 2022

Published: 9 February 2022

Publisher's Note: MDPI stays neutral with regard to jurisdictional claims in published maps and institutional affiliations.

Copyright: (C) 2022 by the authors. Licensee MDPI, Basel, Switzerland. This article is an open access article distributed under the terms and conditions of the Creative Commons Attribution (CC BY) license (https:// creativecommons.org/licenses/by/ $4.0 /)$.

\begin{abstract}
Background: Globally, over 40 million people are estimated to be living with sexually transmitted infection/diseases (STI/Ds), including HIV/AIDS. It is said that sub-Saharan Africa accounts for over a half of that figure, making it the continent most affected with HIV/AIDS and other STI/Ds. This study was designed and conducted to assess the knowledge and prevalence of sexually transmitted diseases, and factors that are associated with it, among female students of a university in southern Nigeria. Methods: This cross-sectional analytical study was conducted among female students in five faculties in the University of Benin, Benin City. The instrument used for the collection of data was a self-administered questionnaire. Data were analyzed with the aid of SPSS, version 22.0. A level of significance was set at $p<0.05$ and descriptive statistics were used to summarize the data. An odds ratio with a $95 \%$ confidence interval for prevalence and factors associated with STI/Ds was computed using binary and multinomial logistic regression models. Results: A total of 423 female students participated in the study. Over half $(224,53.0 \%)$ of the participants have had sexual intercourse. The results show that majority of the respondents $(95.3 \%)$ were aware of STIs and $83.1 \%$ had good knowledge of STIs. The prevalence of STI/Ds among the participants was $27.7 \%$, with gonorrhea being the most frequent STI/D that the respondents reported testing positive for. Conclusion: The present study was able to ascertain a higher prevalence of sexually transmitted diseases among female students. To this end, it is imperative that families and agencies (both government and private agencies) should synergize to remove the embargo seemingly placed on women by our cultures and faith-based institutions regarding sexuality. This may help to improve access to sexual and reproductive health education and commodities for women, thereby play a vital role in reducing the transmission of STI/Ds.
\end{abstract}

Keywords: knowledge; prevalence; sexually transmitted diseases; factors; female students; southern Nigeria

\section{Introduction}

Sexually transmitted infections (STIs) can be curable or incurable, but are most often modifiable diseases or infections which are mainly contracted through unprotected sexual intercourse. The curable STIs include syphilis, gonorrhea and chlamydia, while the incurable but modifiable STIs include human papilloma virus (HPV), hepatitis B, human immune virus (HIV) and herpes simplex [1,2]. According to WHO, 20\% of people living with human immune virus/acquired immunodeficiency syndrome (HIV / AIDS) are in their second decade of life and, each year, one out of every twenty young people contract an STI [1]. Indulging in unprotected sexual intercourse suggests a high-risk predisposition 
to unintended and unwanted pregnancies and STIs, including AIDS, among adolescents and young people. Globally, 33.3 million people are estimated to be living with HIV / AIDS. It is said that sub-Saharan Africa accounts for nearly 22.5 million of the people living with HIV / AIDS, making it the most HIV / AIDS-affected region in the world. Amongst all leading killer diseases globally, HIV / AIDS ranks third, while in Africa, it is the primary cause of death among people between 15 and 29 years of age $[3,4]$.

The literature has many examples demonstrating that people with STIs have a ten-foldincreased chance of HIV infection [5]. Infertility, cervical cancer, chronic pelvic discomfort, recurrent pregnancy loss, premature labor, and newborn/child health issues are among the severe health implications of STIs on numerous aspects of reproductive health $[6,7]$. Even in low- and middle-income nations, STIs have a significant economic impact [7]. The high prevalence of HIV in Africa is linked to a high percentage of STIs that are untreated or inadequately treated $[8,9]$. Africa currently accounts for $20-35 \%$ of the global burden of curable and non-curable STIs [9]. There are no official data for STI prevalence in Nigeria; however, prior studies have found a prevalence of curable STIs ranging from $0 \%$ to $18 \%$ among the low-risk population [10,11] and $23 \%$ among sex workers [12,13]. In Nigeria, the average national seroprevalence of HIV infection among people aged 15 to 49 years is 1.4 percent, with a greater prevalence among high-risk groups (sex workers, men who have sex with men, and drug users) [14,15], accounting for as much as $32 \%$ of HIV infections in the country, though their total population is about $3.4 \%$ of the nations' population. Of these most vulnerable groupsare: women, young people, children and orphans, $3.4 \%$ people living with HIV / AIDS inject drugs (drug users) and 58\% are women [16].

Most African countries have few specialized clinics for STI prevention and treatment due to poor health infrastructure and a shortage of manpower $[9,17]$. People with STIs are more likely to visit pharmacies, patent medication stores, and traditional healers in Africa, according to several studies [18-20]. In addition, to avoid humiliation and stigma at routine health clinics, teenagers and young people frequently self-medicate. Case management, counseling, and behavioral interventions are all part of the overall STI prevention strategy, as are investments in rapid point-of-care diagnostic testing, antimicrobial treatment, vaccine research, and other associated treatments [21-23]. Counseling and behavioral interventions allow caregivers and clients to communicate and discuss measures to avoid STI recurrence and encourage adherence to treatment protocols. At a community level, culturally responsive behavioral change communication programs assist the raising of STI awareness and knowledge, as well as potentially reducing the risk in the population [24].

Furthermore, because of their demonstrated role in facilitating HIV infection, interest in STIs and their care has skyrocketed, increasing vulnerability to other STIs [25]. Increased urbanization, modernization, travel, education, and exposure to Western media have all been related to an increase in the incidence of STIs in emerging nations. Sexual activity has grown as a result of this, particularly among young people [26,27]. STIs, especially in women, are frequently asymptomatic. Multiple sexual partners (premarital and extramarital sex), irregular condom use, and sexual preferences have all been identified as risk factors for STIs $[28,29]$. Previous STIs, contact with a symptomatic partner and weakened immunity are all known risk factors. Notwithstanding the fact that STIs play a significant role in the transmission of the human immunodeficiency virus, they cause significant consequences in terms of morbidity and mortality among infected individuals [25]. The fact that the profile of many diseases varies depending on socioeconomic, cultural, geographic, and environmental factors that exist in various sections of the country, it is, then, very crucial that the design, implementation, and monitoring of focused intervention programs, baseline information on the epidemiology of STIs, the proportion of symptomatic and asymptomatic infections, and other associated risk behaviors are intently and always considered [30].

According to the report of NDHS, 2018, only about $40 \%$ of children in upper primary school who had been engaging in sexual intercourse with two or more partners were using a condom [31]. This report may show why adolescents and young people are 
disproportionately affected by STIs, despite the decline in the prevalence of STIs, including HIV / AIDS, in Nigeria. In a study designed to determine the knowledge and awareness of STIs among adolescents in southwestern Nigeria, it was observed that about $7 \%$ of the adolescents had not heard about sexually transmitted infections prior to the study [32]. The study concluded that only $6.9 \%$ of the adolescents who participated in that study had good knowledge of sexually transmitted infections in terms of knowledge and awareness of mode of transmission, preventive measures, symptoms and curative or treatment measures [32]. Other studies conducted among adolescent girls and young adults in southeastern Nigeria show that STIs among this population are very common [33,34]. We, therefore, undertook this study to determine the levels of knowledge and the prevalence of STIs among female students of the University of Benin and to provide recommendations to the authorities on possible ways to enhance safe sexual practices among students.

\section{Materials and Methods}

\subsection{Study Settings}

The study was conducted in five out of the fourteen faculties in the University of Benin, Edo State Nigeria, from February 2016 to January 2018. The University of Benin is one of the first generational universities in Nigeria and was established in 1970. The university is made up of two campuses: Ekenhuan campus and Ugbowo campus (the main campus) [35]. It is estimated that the university has over 90,000 students in both its part-time and full-time programs. The population of female students in the university is estimated to be in excess of 40,000 students. The 14 faculties and schools include in this study are: faculties of arts; education; agriculture; engineering; environmental sciences; law; management sciences; social sciences; life sciences; physical sciences and pharmacy; schools of medicine, dentistry and basic medical sciences; and well over 70 departments.

\subsection{Sample Size Calculation/Sampling Procedure}

The data analyzed were received from 423 female students across five faculties. The sample size was calculated using the Cochran's formula for the minimum sample size determination in a cross-sectional study. Assuming a 50\% prevalence, 1.96 critical value for $95 \%$ confidence interval, $5 \%$ error margin and 10\% non-response rate using the Cochran's formula [36], $n=\frac{Z^{2} p q}{d^{2}}$, a sample size of 423 was estimated.

A multistage sampling technique was used to recruit 423 female undergraduate student respondents for the study. In stage one, a simple random sampling was used to select five out of the fourteen faculties that make up the university. The selected faculties were arts, basic medical sciences, education, life sciences and management sciences. In stage two, a list of all the departments in each of the five selected faculties were obtained from the university's central record processing unit (CRPU), and numbers were allocated to each department. This was followed by using a computer-generated table of random numbers to select three departments from the five initially selected faculties, making a total of fifteen departments. In stage three, a selection of the level of study was conducted by the simple random sampling method. Fresh students or 100-level students were excluded because it was assumed that they were not yet established in the university system. Three levels of study (200, 300 and 400 levels) were selected from each of the departments that were selected in stage two. In stage four, a list of the total population of female undergraduates in each of the selected departments was obtained from the CRPU office. This aided the allocation of the sampling tool proportionally to each department and to determine the total number of respondents participating from each of the selected departments. Thereafter, lecture halls and hostels of the female students were visited, and requests were made to the female students to participate in the study. Anyone who indicated interest was interviewed, provided the student fell within the inclusion criteria and was from the departments and levels selected. 


\subsection{Research Instrument}

The data were collected using a self-structured questionnaire adapted from the 2013 National HIV / AIDS and Reproductive Health Survey (NARHS) plus [37]. The questionnaire was structured into various sections: socio-demographic characteristics, sexual debut, sexual practices, knowledge of HIV / AIDS and other sexually transmitted infections, and its complications.

\subsection{Data Collection Procedure}

The questionnaire was written in English language and was administered to the respondents on a one-on-one basis. Data were collected by the primary investigator with the help of five research assistants, who were postgraduate students in the same institution. The research assistants were given two days of training on the content of the questionnaire, data collection procedure, research ethics, interviewer skills, seeking for consent and the administration of questionnaires. The data collection lasted three weeks.

\subsection{Variables and Their Measures}

Two outcome indicators were used for the study: knowledge of HIV / AIDS and other STIs and the prevalence of STIs. For knowledge of HIV / AIDS and other STIs, we considered whether the respondents had heard about STIs and HIV/AIDS, the STIs that were known to respondents, routes of their transmissions, and knowledge of their HIV status and that of their sexual partners. The prevalence was based on the question "Tested positive to HIV/AIDS or any other STIs"; a value of 1 or 0 indicated whether a respondent had tested positive for HIV / AIDS or STIs. Respondents who responded "Yes" were coded as " 1 ", while those who responded "No" were coded "0". HIV / AIDS- and STI-related knowledge was computed as the sum of the correct answers to vital questions. For questions assessing HIV/AIDS or other STI infection knowledge, answers were recoded as follows: correct answer $=1$, incorrect answer $=0$. Twelve questions were included in the HIV / AIDS and other STI knowledge total score, meaning that the highest possible total score is 12 . We computed the mean value of the scores. Any respondent who scored below the mean value was classified to have poor knowledge; otherwise, we classified the respondent as having good knowledge.

These variables were examined against all confounding/covariates/controlling variables, which were the socio-demographic characteristics of the respondents. The independent variables included age ( $\leq 19 / 20-24 / \geq 25)$, ethnic group (Edo indigene/non-Edo indigene), religion (Catholics/non-Catholics/Islam/others), marital status (single/married), parent's marital status (living together/divorced and separated/widowed), current academic level (200 level/300 level/400 level), average monthly allowance in NGN (5000-20,000/ 20,001-35,000/35,001-50,000) and current place of residence (living with both parents/living alone/living with single parent/cohabiting/living with husband).

\subsection{Statistical Analysis}

The extracted data were entered into an Excel spread sheet and transported into SPSS for Windows, Version 25.0 Software. The analyses were undertaken in three stages. In the first stage, the frequency and simple proportion were used to describe the characteristics of respondents. In the second stage, bivariate analysis using a Chi-square test was used to test for a significant association between the levels of knowledge of STIs including HIV / AIDS, prevalence of STIs and HIV / AIDS and the various socio-demographic characteristics of respondents. In the third stage, multivariate logistic regression models were estimated to explore the determinants of levels of knowledge of STIs and prevalence of STIs. After the bivariate analysis, variables with a $p$ value $\leq 0.05$ and other plausible variables were further analyzed using multinomial logistic regression to control for confounding. Variables with $p \leq 0.05$ were considered to be significantly associated with the two outcome indicators. 


\subsection{Limitations}

One of the limitations of the study was that some students found it difficult to divulge information that concern their sexual practices, HIV / AIDS status, and whether they had tested positive for STIs. This may be due to social and cultural norms, an attachment to the issue of sexual practices, and stigma attached to STIs and AIDS in Nigeria. This may pose as a drawback or limitation. However, efforts were made by the primary investigator to convince and assure the respondents that the information obtained from them shall be kept confidential. Codes rather than names were used to identify each respondent and their identities were not known even to the researcher; therefore, the blinding technique was employed throughout the study.

\section{Results}

Table 1 shows the socio-demographic and proximate characteristics of the respondents. The mean SD age of the respondents was $21.4 \pm 2.6$ years. Their ages range from 16 to 34 years. Over two thirds-286 (67.6\%) — of the respondents were young adults (they belonged to the 20-24 years age bracket); 81 (19.2\%) were adolescents, that is, $\leq 19$ years; and $56(13.2 \%)$ were adults, aged 25 years old and above. More than half $229(54.2 \%)$ of the respondents were of Benin, $120(28.4 \%)$ and Igbo, 109 (25.8\%) ethnic groups. Esan and Yoruba tribes were $65(15.4 \%)$ and $36(8.5 \%)$, respectively. Other tribes were Urhobo/Isoko 22 (5.2\%), Efik/Ibibio 21 (5.0\%), Etsako 21 (5.0\%), Owan 12 (2.8\%), Ijaw/Itsekiri 10 (2.3\%) and Hausas were $7(1.6 \%)$ of the respondents. Majority, $385(91 \%)$, of the respondents were Christians. Amongst the Christians, more than one third 189 (44.7\%) belonged to the Pentecostal faith, $117(27.7 \%)$ to the Catholic faith and $79(18.6 \%)$ to the Protestant denominations. The remaining 38 (9\%) were distributed among Islam 10 (2.4\%), African Traditional Religion (ATR) 4 (1.0\%) and others, 24 (5.6\%). The majority $(391,92.4 \%)$, of the respondents were single, while $32(7.6 \%)$ were married.

Table 1. Socio-demographic characteristics of the respondents.

\begin{tabular}{ccc}
\hline Variables & Frequency $(\boldsymbol{n = 4 2 3 )}$ & Percent \\
\hline Age group (years) & 1 & \\
$\leq 19$ & 286 & 19.2 \\
$20-24$ & 56 & 67.6 \\
$\geq 25$ & & 13.2 \\
Ethnic Group & 120 & \\
Benin & 109 & 28.4 \\
Igbo & 65 & 25.8 \\
Esan & 36 & 15.4 \\
Yoruba & 22 & 8.5 \\
Urhobo/Isoko & 21 & 5.2 \\
Efik/Ibibio & 21 & 5.0 \\
Etsako & 12 & 5.0 \\
Owan & 10 & 2.8 \\
Ijaw/Itsekiri & 7 & 2.3 \\
Hausa & & 1.6 \\
Religion & 189 & \\
Pentecostal & 117 & 44.7 \\
Catholics & 79 & 27.6 \\
Protestant & 10 & 18.7 \\
Islam & 4 & 2.4 \\
ATR & 24 & 1.0 \\
Others & & 5.6 \\
Marital status & 391 & 92.4 \\
Single & 32 & 7.6 \\
Married & & \\
\hline & & \\
\hline
\end{tabular}


Table 1. Cont.

\begin{tabular}{ccc}
\hline Variables & Frequency $(\boldsymbol{n = 4 2 3 )}$ & Percent \\
\hline Faculty & 132 & \\
Education & 105 & 31.2 \\
Arts & 76 & 24.8 \\
Life Sciences & 62 & 18.0 \\
Management Sciences & 48 & 14.7 \\
Basic Medical Sciences & & 11.3 \\
Current level of study & 61 & \\
200 level & 193 & 14.4 \\
300 level & 169 & 45.6 \\
400 level & & 40.0 \\
(NGN) & 336 & \\
5000-20,000 & 64 & 79.4 \\
20,001-35,000 & 23 & 15.1 \\
35,001-50,000 & & 5.5 \\
Respondents' current & & \\
residence & 221 & 52.2 \\
Both parents & 78 & 18.4 \\
Alone & 66 & 15.6 \\
Single parent & 32 & 7.6 \\
Husband & 26 & 6.2 \\
Boy friend &
\end{tabular}

Mean age \pm SD of the respondents $=21.4 \pm 2.6$ years, ATR $=$ African traditional religion, Others = Jehovah's Witnesses (JW), Mormons, Atheists, etc.

More than a quarter of the respondents $(132,31.2 \%)$, were drawn from the faculty of education, $105(24.8 \%)$ from arts, $76(18.0 \%)$ from life sciences, $62(14.7 \%)$ from management sciences and $48(11.3 \%)$ from basic medical sciences. Sixty-one $(14.4 \%)$ of the respondents were in the 200 level of their study, 193 (45.6\%) were in the 300 level, while $169(40.0 \%)$ were in the 400 level. The mean average monthly allowance of the respondents was NGN $17,592.2 \pm 9676.8$. Over three quarters $(336,(79.4 \%)$ of the respondents had an average monthly allowance of NGN 5000-20,000, 64 (15.1\%) had an average of NGN 20,001-35,000 and $23(5.4 \%)$ of the respondents had an average of NGN 35,001-50,000. The majority of the respondents $(221,52.2 \%)$ currently live with both parents, $78(18.4 \%)$ live alone, $66(15.6 \%)$ live with a single parent, $32(7.6 \%)$ live with a husband, and $26(6.1 \%)$ live with a boyfriend.

Table 2 shows the socio-demographic characteristics of the respondents' parents. Concerning the respondents' parental marital status, $300(71.0 \%)$ had their parents still living together, in comparison to $78(18.4 \%)$ whose parents were either divorced or separated. Forty-five $(10.6 \%)$ of the study population were children of single parents or orphaned. The majority of respondents' fathers $(274,64.8 \%)$, and mothers $(258,61.0 \%)$, had a tertiary level of education, while $(99,23.4 \%)$ and $(94,22.2 \%)$ of the respondents' fathers and mothers, respectively, were in the skill level 4.

Table 2. Socio-demographic characteristics of the respondents' parents.

\begin{tabular}{ccc}
\hline Variables & Frequency $(\boldsymbol{n = 4 2 3 )}$ & Percentage $(\mathbf{\%})$ \\
\hline Parents marital status & & \\
Living together & 300 & 71.0 \\
Divorced/separated & 78 & 18.4 \\
Widowed & 45 & 10.6 \\
Father's education & 5 & 1.2 \\
None & 36 & 8.5 \\
Primary & 108 & 25.5 \\
Secondary & 274 & 64.8 \\
Tertiary & & \\
\hline
\end{tabular}


Table 2. Cont.

\begin{tabular}{ccc}
\hline Variables & Frequency $(\boldsymbol{n = 4 2 3 )}$ & Percentage (\%) \\
\hline Mother's education & 8 & \\
None & 51 & 2.0 \\
Primary & 106 & 12.0 \\
Secondary & 258 & 25.0 \\
Tertiary & & 61.0 \\
Father's occupation & 34 & \\
Skill level 1 & 102 & 8.1 \\
Skill level 2 & 188 & 24.1 \\
Skill level 3 & 99 & 44.4 \\
Skill level 4 & & 23.4 \\
Mother's occupation & 45 & 10.6 \\
Skill level 1 & 113 & 26.7 \\
Skill level 2 & 171 & 40.4 \\
Skill level 3 & 94 & 22.2 \\
Skill level 4 & & \\
\hline
\end{tabular}

Table 3 shows the prevalence of sexual practices among the respondents. The prevalence of sexual intercourse among the studied population was found to be $53.0 \%$, in comparison to $199(47.0 \%)$ who had not had sexual intercourse. Among those who had had sex, the majority $(144,64.3 \%)$, had their sexual debut within the age of adolescence ( $\leq 19$ years), $78(34.8 \%)$ had theirs as young adults, while a very insignificant number of the respondents, $2(0.9 \%)$, had their sexual debut as adults ( $\geq 25$ years). The mean SD age of sexual debut was $18.3 \pm 2.3$ years. The majority of those who had experienced sexual intercourse $(140,62.4 \%)$, had their sexual debut with their boyfriends in comparison to those who had theirs with their casual friends $47(21.0 \%)$, relative/family member $25(11.2 \%)$, and husband $12(5.4 \%)$. Nine $(4.0 \%)$ of the respondents who had had sexual intercourse were not sexually active in the last six months, compared with $112(50.0 \%)$ who had sex 1-4 times, 95 (42.4\%) 5-19 times and 8 (3.6\%) 20 or more times. Of the respondents who had had sex, $97(43.3 \%)$ had had multiple sexual partners in the last six months, among which $39(40.2 \%)$ had two sexual partners, while $58(59.8 \%)$ had three or more sexual partners in the last six months.

Table 3. Prevalence of sexual practices among the respondents.

\begin{tabular}{ccc}
\hline Variables & Frequency $(\boldsymbol{n}=\mathbf{4 2 3})$ & Percent \\
\hline Had Sex & & \\
Yes & 224 & 53.0 \\
No & 199 & 47.0 \\
Age at sexual debut (years) & $(n=224)$ & \\
$\leq 14$ & 14 & 6.3 \\
$15-19$ & 130 & 38.0 \\
$20-24$ & 78 & 0.9 \\
$\geq 25$ & 2 & 62.4 \\
Partner at sexual debut & & 21.0 \\
Boyfriend & 140 & 11.2 \\
Casual friend & 47 & 5.4 \\
Relative/family member & 25 & \\
Husband & 12 & 23.2 \\
Time since most recent sex & & 63.4 \\
Days ago & 52 & 12.5 \\
Weeks ago & 142 & 0.9 \\
Last six months & 28 & \\
Years ago & 2 & \\
\hline
\end{tabular}


Table 3. Cont.

\begin{tabular}{|c|c|c|}
\hline Variables & Frequency $(n=423)$ & Percent \\
\hline \multicolumn{3}{|l|}{ Last sex partner } \\
\hline Boyfriend & 166 & 74.0 \\
\hline Husband & 30 & 13.4 \\
\hline Casual friend & 14 & 6.3 \\
\hline Relative/family member & 14 & 6.3 \\
\hline \multicolumn{3}{|l|}{ Frequency of sexual intercourse in the last six months } \\
\hline 0 & 9 & 4.0 \\
\hline $1-4$ & 112 & 50.0 \\
\hline $5-9$ & 65 & 29.0 \\
\hline $10-14$ & 17 & 7.6 \\
\hline $15-19$ & 13 & 5.8 \\
\hline$>20$ & 8 & 3.6 \\
\hline \multicolumn{3}{|l|}{ Multiple sex partners in the last six months } \\
\hline Yes & 97 & 43.3 \\
\hline No & 127 & 56.7 \\
\hline Number of multiple sexual partner in the last six months & $(n=97)$ & \\
\hline 2 & 39 & 40.2 \\
\hline$\geq 3$ & 58 & 59.8 \\
\hline
\end{tabular}

Table 4 revealed that, overall, the knowledge of STIs among the respondents was very high $-403(95.3 \%)$. The most reported STI known to the respondents was gonorrhea 398 (98.8\%), followed by HIV / AIDS 384 (95.3\%), staphylococcus and syphilis, 340 (84.4\%) and $328(81.4 \%)$, respectively. The least reported STI was hepatitis B $23(5.7 \%)$. Unprotected sexual intercourse, $380(94.3 \%)$, and having multiple sexual partners, $323(80.1 \%)$, were the most reported routes of transmission of STIs. On the other hand, the least reported route of transmission of STIs and HIV / AIDS was mother-to-child-transmission (MTCT), $42(10.4 \%)$. The study further revealed that only $267(63.1 \%)$ of the respondents knew their HIV status at the time of the study, while among those who were sexually active, only about one half of them $(116,51.8 \%)$, knew the HIV status of their sexual partners. Overall, composite knowledge scores of the respondents showed that the majority $(335,83.1 \%)$, had good knowledge of STIs, as compared to $68(16.9 \%)$ who had poor knowledge.

Table 5 shows the binary regression model for determinants of respondents' level of knowledge of STIs. The variables in the model explained $10.4 \%-17.5 \%$ of the variation observed in the factors that influence the levels of STI knowledge among the respondents. The model was statistically useful (omnibus tests of model coefficient $=44.461, p<0.001$ ). Respondents who were from the faculties of arts, education and life sciences were less likely to have good knowledge of (STIs) —with odds ratios of 0.832 (95\% CI: $0.29-2.38$ ), 0.393 (95\% CI: $0.15-1.03$ ) and 0.568 (95\% CI: 0.20-1.61), respectively-when compared with respondents from a management sciences faculty $(p>0.05)$. Respondents who were $\leq 19$ and those 20-24 years were 0.442 and 0.854 less likely to have good knowledge of STIs when compared with those who were 25 years old and above (95\% CI: $0.12-1.57$ and 95\% CI: $0.29-2.56, p>0.05$ ). Respondents who were living with their both parents were statistically significantly (three times) more likely to have good knowledge of STIs when compared with respondents who were living with their husband $(p=0.042,95 \%$ CI: 1.05-12.08). The respondents who were living with a single parent and alone were also more likely to have good knowledge of STIs when compared with those living with husbands, but these variables were not statistically significant $(p>0.05)$. Respondents whose father's education was either primary or none were statistically significantly less likely to have good knowledge of STIs when compared with respondents whose fathers had at least a secondary level of education (95\% CI: $0.14-0.98, p=0.046)$. 
Table 4. Knowledge of sexually transmitted infections among the respondents.

\begin{tabular}{ccc}
\hline Variables & Frequency & Percent \\
\hline Ywareness of HIV / AIDS and STIs & $(n=423)$ & \\
No & 403 & 95.3 \\
Known STIs * & 20 & 4.7 \\
Gonorrhea & $(n=403)$ & 98.8 \\
HIV /AIDS & 398 & 95.3 \\
Staphylococcus & 384 & 84.4 \\
Syphilis & 340 & 81.4 \\
Human papilloma virus (HPV) & 328 & 54.6 \\
Chlamydia & 220 & 53.6 \\
Herpes simplex virus (HSV) & 216 & 42.9 \\
Hepatitis B & 173 & 5.7 \\
STIs routes of transmission * & 23 & 94.3 \\
Unprotected sexual intercourse & & 80.1 \\
Multiple sexual partners & 380 & 68.7 \\
Blood transfusion & 323 & 60.0 \\
Sharing sharp objects & 277 & 10.4 \\
MTCT & 243 & 63.1 \\
Knowledge of respondents' HIV status & 42 & 36.9 \\
Yes & & \\
No & 267 & 51.8 \\
Level of knowledge of STIs & 156 & 48.2 \\
Good & $(n=224)$ & 83.1 \\
Poor & 116 & 16.9 \\
\hline Knowledge of HIV status of sexual partner & 108 & \\
\hline No & 335 & \\
\hline
\end{tabular}

${ }^{*}$ Multiple responses.

Table 5. Binary logistic regression model for determinants of respondents' level of knowledge of STIs.

\begin{tabular}{|c|c|c|c|}
\hline Predictors & $\begin{array}{l}\text { Regression } \\
\text { Coefficient }(\beta)\end{array}$ & AOR $(95 \% \mathrm{CI})$ & $p$-Value \\
\hline \multicolumn{4}{|l|}{ Faculty } \\
\hline Art & -0.184 & $0.832(0.29-2.38)$ & 0.732 \\
\hline Basic medical sciences & 0.209 & $1.233(0.35-4.38)$ & 0.747 \\
\hline Education & -0.933 & $0.393(0.15-1.03)$ & 0.058 \\
\hline Life sciences & -0.566 & $0.568(0.20-1.61)$ & 0.287 \\
\hline Management sciences ** & & 1 & \\
\hline \multicolumn{4}{|l|}{ Age group (years) } \\
\hline$\leq 19$ & -0.817 & $0.442(0.12-1.57)$ & 0.208 \\
\hline $20-24$ & -0.157 & $0.854(0.29-2.56)$ & 0.779 \\
\hline$\geq 25 * *$ & & 1 & \\
\hline \multicolumn{4}{|l|}{ Ethnic group } \\
\hline Edo indigene & -0.237 & $0.789(0.45-1.38)$ & 0.409 \\
\hline Non-Edo indigene ${ }^{* *}$ & & 1 & \\
\hline \multicolumn{4}{|l|}{ Parents' marital status } \\
\hline Living together & -0.521 & $0.594(0.15-2.39)$ & 0.463 \\
\hline Divorced/separated & 0.763 & $2.145(0.57-8.07)$ & 0.259 \\
\hline Widowed $* *$ & & 1 & \\
\hline \multicolumn{4}{|l|}{ Current level of study } \\
\hline 200 level & 0.556 & $1.744(0.62-4.91)$ & 0.292 \\
\hline 300 level & -0.253 & 0.777 (0.40-1.53) & 0.463 \\
\hline 400 level ** & & 1 & \\
\hline
\end{tabular}


Table 5. Cont.

\begin{tabular}{cccc}
\hline Predictors & $\begin{array}{c}\text { Regression } \\
\text { Coefficient }(\boldsymbol{\beta})\end{array}$ & AOR (95\% CI) & $p$-Value \\
\hline Respondents' current residence & & & \\
Both parents & 1.270 & $3.560(1.05-12.08)$ & $0.042 *$ \\
Single parent & 0.902 & $2.465(0.45-13.59)$ & 0.300 \\
Alone & 1.408 & $4.089(0.97-17.26)$ & 0.055 \\
Husband & & 1 & \\
Father's education & & & $0.046^{*}$ \\
$\quad$ Primary & & $0.364(0.14-0.98)$ & \\
$\geq$ Secondary ** & -1.010 & 1 & \\
\hline
\end{tabular}

${ }^{* *}$ Reference category, ${ }^{*}$ Statistically significant, $\mathrm{R}^{2} 10.4-17.5 \%, \mathrm{CI}=$ confidence interval, omnibus tests of model coefficient $=44.461(p<0.001)$, AOR $=$ adjusted odds ratio.

Table 6 shows the prevalence of STIs among the respondents. The prevalence of a positive test for STIs among the sexually active respondents was found to be $27.7 \%$. The most prevalent positive STI test was for gonorrhea $26(41.9 \%)$, then syphilis $18(29.0 \%)$, staphylococcus 13 (21.0\%), Chlamydia 6 (9.7\%), HIV / AIDS 4 (6.5\%) and Hepatitis B $3(4.8 \%)$. Eight percent of the respondents used antibiotics for the treatment of the STI they tested positive for, while $6.5 \%$ used herbal mixture and antiretroviral therapy (ART). Regarding the place of treatment, $48.4 \%$ were treated in pharmacy shop, $25.8 \%$ in a hospital, and $12.9 \%$ in a laboratory center, while $6.5 \%$ were treated in a patent medicine store and herbal healer's home.

Table 6. Prevalence of STIs among respondents.

\begin{tabular}{ccc}
\hline Variables & Frequency & Percent \\
\hline Positive test for STIs & $(n=224)$ & 27.7 \\
Yes & 62 & 72.3 \\
No & 162 & \\
STIs ever tested positive for * & $(n=62)$ & 41.9 \\
Gonorrhea & 26 & 29.0 \\
Syphilis & 18 & 21.0 \\
Staphylococcus & 13 & 9.7 \\
Chlamydia & 6 & 6.5 \\
HIV/AIDS & 4 & 4.8 \\
Hepatitis B & 3 & 87.0 \\
Drug/treatment & & 6.5 \\
Antibiotics & 54 & 6.5 \\
Herbal mixture & 4 & \\
Antiretroviral therapy (ART) & 4 & 48.3 \\
Place of treatment & & 25.8 \\
Pharmacy shop & 30 & 12.9 \\
Hospital & 16 & 6.5 \\
Laboratory & 8 & 6.5 \\
Patent medicine store & 4 & \\
Herbal healer home & 4 &
\end{tabular}

* Multiple responses.

Table 7 shows the socio-demographic characteristics of the respondents and positive test for STIs. Three (13.0\%) of the respondents in the age group 19 years old and below had tested positive for STIs compared with 31 (20.4\%) of those in the age group 20-24 years old and $28(57.1 \%)$ of those in the age group 25 years old and above. This association was statistically significant $(p<0.001)$. Thirty-four $(17.7 \%)$ of the single respondents had tested positive for STIs compared with $28(87.5 \%)$ of those who are married, and this association was also significant $(p<0.001)$. About one quarter $8(23.5 \%)$ of respondents in the 200 level had tested positive for STIs compared with more than one third $(38,35.2 \%)$ in the 300 level and one fifth $(16,20.0 \%)$ in the 400 level. The association was also statistically 
significant $(p=0.045)$. As the average monthly allowance of the respondents increases, there is a corresponding increase in the number of positive STI tests. Thirty-seven $(22.0 \%)$ of respondents whose monthly allowance was NGN 5000-20,000 had tested positive for STIs compared with 19 (42.2\%) whose allowance was within the NGN 20,001-35,000 and $6(54.5 \%)$ whose allowance was NGN 35,001-50,000. The association was statistically significant $(p=0.003)$. Seventeen $(18.1 \%)$ respondents who were living with both of their parents had tested positive for STIs compared with $8(22.2 \%)$ who live with a single parent, $4(11.1 \%)$ who live alone, $5(19.2 \%)$ who live with their boyfriend and $28(87.5 \%)$ who live with their husband. The association was found to be statistically significant $(p<0.001)$.

Table 7. Socio-demographic characteristics and positive test to STIs among respondents.

\begin{tabular}{|c|c|c|c|}
\hline \multirow{2}{*}{ Variables } & \multicolumn{2}{|c|}{ Positive Test for STIs } & \multirow{2}{*}{$p$-Value } \\
\hline & Yes $(n=62)$ & No $(n=162)$ & \\
\hline \multicolumn{4}{|l|}{ Age group (years) } \\
\hline$\leq 19$ & $3(13.0)$ & $20(87.0)$ & \multirow{3}{*}{$<0.001^{+, *}$} \\
\hline $20-24$ & $31(20.4)$ & $121(79.6)$ & \\
\hline$\geq 25$ & $28(57.1)$ & $21(42.9)$ & \\
\hline \multicolumn{4}{|l|}{ Ethnic group } \\
\hline Edo indigene & $33(28.2)$ & $84(71.8)$ & \multirow[t]{2}{*}{$0.854^{+}$} \\
\hline Non-Edo indigene & $29(27.1)$ & $78(72.9)$ & \\
\hline \multicolumn{4}{|l|}{ Religion } \\
\hline Catholics & $17(29.8)$ & $40(70.2)$ & \multirow{4}{*}{$0.334^{\dagger}$} \\
\hline Non-Catholics & $37(25.0)$ & $111(75.0)$ & \\
\hline Islam & $2(33.3)$ & $4(66.7)$ & \\
\hline Others & $6(46.2)$ & $7(53.8)$ & \\
\hline \multicolumn{4}{|l|}{ Marital status } \\
\hline Single & $34(17.7)$ & $158(82.3)$ & \multirow[t]{2}{*}{$<0.001^{+, *}$} \\
\hline Married & $28(87.5)$ & $4(12.5)$ & \\
\hline \multicolumn{4}{|l|}{ Parents marital status } \\
\hline Living together & $47(30.3)$ & 108 (69.7) & \multirow{3}{*}{$0.328^{+}$} \\
\hline Divorced/separated & $11(24.4)$ & $34(75.6)$ & \\
\hline Widowed & $4(16.7)$ & $20(83.3)$ & \\
\hline \multicolumn{4}{|l|}{ Current level of study } \\
\hline 200 level & $8(23.5)$ & $26(76.5)$ & \multirow{3}{*}{$0.045^{+, *}$} \\
\hline 300 level & $38(35.2)$ & $70(64.8)$ & \\
\hline 400 level & $16(19.5)$ & $66(80.5)$ & \\
\hline \multicolumn{4}{|c|}{$\begin{array}{l}\text { Average monthly allowance } \\
\text { (NGN) }\end{array}$} \\
\hline $5000-20,000$ & $37(22.0)$ & $131(78.0)$ & \multirow{3}{*}{$0.003^{\dagger, *}$} \\
\hline $20,001-35,000$ & $19(42.2)$ & $26(57.8)$ & \\
\hline $35,001-50,000$ & $6(54.5)$ & $5(45.5)$ & \\
\hline \multicolumn{4}{|l|}{$\begin{array}{l}\text { Respondents' current } \\
\text { residence }\end{array}$} \\
\hline Both parents & $17(18.1)$ & $77(81.9)$ & \multirow{5}{*}{$<0.001^{+, *}$} \\
\hline Single parent & $8(22.2)$ & $28(77.8)$ & \\
\hline Alone & $4(11.1)$ & $32(88.9)$ & \\
\hline Boyfriend & $5(19.2)$ & $21(80.8)$ & \\
\hline Husband & $28(87.5)$ & $4(12.5)$ & \\
\hline \multicolumn{4}{|l|}{ Knowledge of STIs } \\
\hline Good knowledge & $47(25.0)$ & $141(75.0)$ & \multirow[t]{2}{*}{$0.055^{+}$} \\
\hline Poor knowledge & $14(40.0)$ & $21(60.0)$ & \\
\hline
\end{tabular}

* Statistically significant, ${ }^{+}$Pearson, Chi-square, ${ }^{+}$Fisher's Exact.

Table 8 shows Binary logistic regression model for determinants of respondents positive test to STIs. The variables in the model explained that $24.8-36.0 \%$ of the variation was observed in the factors that influence a positive test to STIs among the respondents. The model was statistically useful (omnibus tests of model coefficient $=63.697, p<0.001$ ). Respondents who were not married (single respondents) were found to be statistically 
significantly (34 times) more likely to have tested positive for STIs when compared with respondents who were married ( $p<0.001,95 \%$ CI: 5.08-232.85). Respondents who had good knowledge of STIs were found to be more likely to have tested positive to STIs with an odds ratio of 1.760 (95\% CI: $0.52-5.98$ and $p=0.365)$, when compared with those who had poor knowledge of STIs.

Table 8. Binary logistic regression model for determinants of respondents' positive test to STIs.

\begin{tabular}{|c|c|c|c|}
\hline Predictors & Regression Coefficient $(\beta)$ & AOR $(95 \% \mathrm{CI})$ & $p$-Value \\
\hline \multicolumn{4}{|l|}{ Age group (years) } \\
\hline$\leq 19$ & 0.285 & $1.33(0.23-7.65)$ & 0.750 \\
\hline $20-24$ & -0.263 & $0.77(0.23-2.57)$ & 0.669 \\
\hline$\geq 25^{* *}$ & & 1 & \\
\hline \multicolumn{4}{|l|}{ Marital status } \\
\hline Single & 3.538 & $\begin{array}{c}34.39 \\
(5.08-232.85)\end{array}$ & $<0.001$ * \\
\hline Married ** & & 1 & \\
\hline \multicolumn{4}{|c|}{$\begin{array}{l}\text { Average monthly allowance } \\
(\mathrm{NGN})\end{array}$} \\
\hline $5000-20,000$ & 0.978 & $2.66(0.52-13.67)$ & 0.242 \\
\hline $20,001-35,000$ & 0.916 & $2.50(0.42-15.01)$ & 0.316 \\
\hline $35,001-50,000 * *$ & & 1 & \\
\hline \multicolumn{4}{|c|}{ Respondents' current residence } \\
\hline Both parents & 0.118 & $1.13(0.36-3.56)$ & 0.840 \\
\hline Single parent & -0.056 & $0.95(0.25-3.57)$ & 0.934 \\
\hline Alone & 0.904 & $2.47(0.55-11.13)$ & 0.239 \\
\hline Husband ** & & 1 & \\
\hline \multicolumn{4}{|l|}{ Mother's education } \\
\hline$\leq$ Primary & -0.188 & $0.83(0.29-2.37)$ & 0.726 \\
\hline$\geq \overline{\text { Secondary }} * *$ & & 1 & \\
\hline \multicolumn{4}{|l|}{ Knowledge of STIs } \\
\hline Good knowledge & 0.564 & $1.76(0.52-5.98)$ & 0.365 \\
\hline Poor knowledge $* *$ & & 1 & \\
\hline Constant & -2.964 & 0.052 & 0.003 \\
\hline
\end{tabular}

** Reference category, ${ }^{*}$ Statistically significant, $\mathrm{R}^{2} 24.8-36.0 \%, \mathrm{CI}=$ confidence interval, omnibus tests of model coefficient $=63.697(p<0.001)$, AOR $=$ adjusted odds ratio.

\section{Discussion}

From this study, it is found that $53.0 \%$ of the study participants had a history of sexual intercourse. The mean age of sexual debut was $18.30 \pm 2.33$ years. The observed number of sexually active respondents was slightly lower than the finding of a similar study conducted in Ekiti State University, southwest Nigeria, which found that $60.8 \%$ of the female students were sexually active and their mean age of debut was 19.11 years [38]. The observed age at sexual debut is also comparable to the report from a study conducted among female students in University of Ibadan, southwest Nigeria. The report showed that the mean age at sexual debut of the participants was $19 \pm 2.3$ years [39], and a study in four states of Nigeria reported the age for sexual initiation in these states to be 17.53 years [40]. The result is also in line with the finding in southeast Ethiopia, where it was found that the age of sexual debut of the female undergraduate students in Madawalabu University was $18.19 \pm 1.83$ years [41]. This study further revealed, through logistic regression analysis, that respondents who were at most 24 years old (young people) were very much more sexually active than those who were at least 25 years old. Life sciences students were the least likely to engage in sexual intercourse in comparison to other faculties in this study. This study also revealed that the average allowance each respondent received per month may not be a contributing factor to such an individual being involved in a sexual relationship as the binomial logistic regression analysis had shown.

The finding of this study is in support of earlier surveys on sexual behaviors of young people. The age of sexual debut and involvement in sexual activity, as found in this study, 
can be explained in the light of different influencing factors, which include precocious onset of secondary sexual development and maturation, followed by the natural increase in sex hormone secretions known to stimulate sexual urges in adolescents and young adults much more than older people, peer pressure and increasing socioeconomic problems that prevail in our environment and most sub-Saharan African countries. Furthermore, sociocultural and religious beliefs contribute a large extent to early sexual debut and a general sexual life in some parts of Nigeria, especially in the northern part and Islamic-religion-dominated areas. The implication of this early sexual debut is an increase in sexual and obstetric problems such as obstetric fistula, STDs and other socio-economic problems which may include poverty, illiteracy and social vices. It has been proven that due to the patriarchal nature of African society and cultural norms, men often were the first initiators of sexual advances to women, with the latter most often having no choice than to oblige, which may be due to the need for protection or economic reasons $[42,43]$. The education of girls and economic empowerment of women will play a greater role in decreasing dependency on men. This, in turn, will enable women to be economically independent and, therefore, be able to negotiate safe sex, deciding when, how, and with whom to have sex.

Ninety-five percent $(95.3 \%)$ of the study participants were aware of STIs and this translated into good knowledge of STIs (83.1\%). The overall knowledge here is greater than the $68 \%$ reported by the National HIV / AIDS and Reproductive Health Survey, 2013 [37]. The most frequent STIs reported by the respondents were gonorrhea $98.8 \%$ and HIV/AIDS $95.3 \%$, with unprotected sexual intercourse, $94.3 \%$, and multiple sexual partners, $80.1 \%$, being the most reported routes of transmission of STIs. However, a logistic regression analysis of the level of knowledge of STIs showed that respondents who were living with both parents were as likely to have good knowledge of STIs when compared to those living with their husband. This suggests that parental guidance and family life education from these parents may be contributing to good knowledge of STIs among this group of respondents. The unmarried respondents in this study had better knowledge of STIs than the married respondents, and those who were younger by age also had better knowledge than those who were older. This may suggest that the younger respondents, who also constitute most of the unmarried participants in this study, were more exposed to information regarding STIs and HIV/AIDS.

The study also showed an association between respondents' fathers' education and respondents' level of STI knowledge. Those whose fathers had, at most, a primary-level education were more predisposed to the risk of not having good knowledge of STIs. This also suggests that a university education was not indicative of a better knowledge of sexually transmitted diseases. More than half of all the respondents had knowledge of both their HIV status and that of their sexual partners, which may suggest that the respondents were being careful and mindful of their reproductive health status. This study is similar, in terms of awareness of STIs, to the study conducted in Ekiti state, southwest Nigeria. In that study, the authors reported that $93 \%$ of the respondents were aware of STIs, but had a very poor knowledge score of STIs including HIV / AIDS (6.9\%) [32]. The difference could be because the Ekiti study was conducted among secondary school students; therefore, it is expected that they should have less knowledge of STIs compared with those in university. The high level of knowledge from this study shows that the health education and awareness effort on STIs including HIV / AIDS being carried out by health facilities, government agencies, and NGOs are yielding a positive outcome among young people; therefore, these efforts should be continued. Furthermore, public health attention should focus more on married women when designing interventions for reducing the burden of STIs because they were identified as having a lower STI knowledge score when compared with unmarried women in this study population.

The prevalence of STIs among the sexually active respondents in this study was $27.7 \%$, and the most reported STI that the respondents had ever tested positive for (life time positive test) was N.gonorrhea (gonorrhea), followed by Treponema pallidum (syphilis), Staphylococcus aureus, Chlamydia trachomatis (chlamydia), HIV/AIDS and the hepatitis 
$B$ virus. The prevalence in this study is higher than that reported among undergraduate female students of Ambo University, Central Ethiopia [3], in southeast Nigeria [34], from a study among adolescent girls in Port Harcourt, South-south [33], among young people in a community close to the University of Benin, Benin City [44], and among postprimary adolescents and female students of tertiary institutions in Imo State, southeastern Nigeria [45].

Approximately three quarters of the respondents who had tested positive for an STI were treated in a pharmacy shop, by a laboratory technician, patent medicine vendors or by a herbal healer in a herbal home, while only a quarter had received their treatment in a hospital. Most young people preferred seeking health care from patent medicine stores and pharmacy shops, especially when this is a reproductive health issue, except in complicated situations [33]. This attitude may be due to feelings of shame, fear of stigmatization, and the attitude of health workers in the hospital. Many of the health institutions in Nigeria are not adolescent- and youth-friendly. Young people complain of a lack of privacy, negative comments, and insults from health workers whenever they attend health centers for reproductive health issues $[33,46]$. It is, therefore, very important that effort is made to reorient and train health-care providers in government hospitals for adolescent- and youth-friendly skills. This training is important because the current lack of adolescent- and youth-friendly skills among health-care providers makes young people more likely to visit a pharmacy shop or patent medicine store to purchase antibiotics or be treated when infected with an STI. These institutions are less likely to identify the real causative agent of the infection and, thereby, mistreat the patient, potentially also creating a drug-resistant strain of that STI.

The study also found out that marital status and age were associated with respondents testing positive for STIs, but a good knowledge of STIs is not a variable which impacts the chance of an individual testing positive for an STI $[33,47]$. Specifically, more married respondents and those who were 25 years old and above in this study had tested positive for STIs than unmarried and younger respondents, yet those who were single were as likely to test positive when compared to the married respondents. This may not show the true situation as it is compulsory for pregnant women to always undergo screening tests for STIs during the time of pregnancy. Therefore, the result showing that more married women and respondents who were 25 years old and above and had tested positive for STIs may be more reflective of the screening tests for STIs carried out during pregnancies than normal occurrence. This suggest that there is greater chance of contracting STIs when one is engaged in risky sexual behavior, such as multiple sexual relationships, which was found to be higher among single respondents. This may also suggest that being young and single is a risk factor for testing positive to STIs. The explanation for this may be due to the fact that those who were 25 years old and above may have had more sexual episodes than the younger people, as this study did not conduct STI tests for the respondents but relied on information from previous tests conducted by the respondents.

\section{Conclusions and Policy Recommendations}

The majority of the respondent were sexually active, with the larger proportion starting sexual activity at a young age and $53.0 \%$ prevalence of sexual intercourse. The majority of the respondents were aware of STIs and had a good knowledge score of STIs and HIV / AIDS. Current place of residence and father's education were factors that positively influenced good knowledge scores among the study participants. We also found that an appreciable number of the study participants had tested positive for at least one STI and the majority did not seek treatment in a hospital. The ages of the study participants and their marital status were the significant determinants of positive tests to STIs. The result revealed that respondents who were living with both parents and those whose father's level of education were at least secondary level were more likely to have good knowledge of STIs. The sexual and reproductive health of the reproductive-aged women was a crucial indicator for the determinant of the health of the family and the future generation. To this 
end, it is imperative that families and agencies (both government and private agencies) should synergize to remove the embargo seemingly placed on women by cultures and faith-based institutions regarding sexuality. This may help to improve access to sexual and reproductive health education and commodities for women, thereby playing a vital role in reducing the spread of STI/Ds.

Based on the findings from the study, the following recommendations are made with the belief that their implementation will be of great importance in improving the sexual and reproductive health of young people: (i) There is a need to implement comprehensive adolescent and young people's friendly health services to increase students' access to sexual and reproductive health information and services. (ii) Family Life Education (FLE), which is an integral part of the basic school curriculum, should be implemented so that young people will be equipped with adequate sexual and reproductive health information to enable them to make informed decisions about sexual issues. (iii) There is a need to ensure that control programs redirect efforts at sexual behaviors that put young people at greater risk of STIs, and target young adolescents before their sexual debut. (iv) Health-care workers should educate female students and their male partners on the need for them to seek for help concerning their sexual health issues.

Author Contributions: Conceptualization, C.N.; methodology, C.N.; formal analysis, C.N.; investigation, C.N. and V.Y.A.; data curation, O.N. and C.N.; writing-original draft preparation, C.N. writing-review and editing, C.N., V.Y.A. and O.N.; supervision, V.Y.A.; project administration, C.N. and V.Y.A.; funding acquisition, C.N. and O.N. All authors have read and agreed to the published version of the manuscript.

Funding: This research received no external funding.

Institutional Review Board Statement: Ethical approval was obtained from the Research and Ethics Committee, College of Medical Sciences, University of Benin with Protocol Number of Ethical Clearance-CMS/REC/2017/025. All respondents in this study were given code numbers and no names were recorded. Information collected was not linked to participants in any way and their names or identifiers will never be used in any publication or reported from this study. The respondents were assured that there would be no penalties or loss of benefits for refusal to participate in the study or withdrawal from it.

Informed Consent Statement: Consent was obtained from the female students and the objectives of the study were well communicated to them. Participation was purely voluntary and there was no inducement or undue influence on participants. Confidentiality and privacy were respected during the study as all the participants were assured that their identity and information given will be kept secret and will not be disclosed.

Data Availability Statement: The data used in this research are not available for the public due to the privacy agreement with the study participants; however, the data will be made available on request from the corresponding author.

Conflicts of Interest: The authors declare no conflict of interest.

\section{References}

1. Centers for Disease Control and Prevention. STDs in Adolescents and Young Adults—2018 Sexually Transmitted Diseases Surveillance. 2019. Available online: https://www.cdc.gov/std/stats18/adolescents.htm (accessed on 19 October 2020).

2. Sexually Transmitted Infections (STIs). Available online: https://www.who.int/news-room/fact-sheets/detail/sexuallytransmitted-infections-(stis) (accessed on 30 December 2021).

3. Abdissa, B.; Addisie, M.; Seifu, W. Premarital Sexual Practices, Consequences and Associated Factors among Regular Undergraduate Female Students in Ambo University, Oromia Regional State, Central Ethiopia, 2015. Health Sci. J. $2017,11,1$. [CrossRef]

4. Arega, W.L.; Zewale, T.A.; Bogale, K.A. Premarital sexual practice and associated factors among high school youths in Debretabor town, South Gondar zone, North West Ethiopia, 2017. BMC Res. Notes 2019, 12, 314. [CrossRef]

5. Lucar, J.; Hart, R.; Rayeed, N.; Terzian, A.; Weintrob, A.; Siegel, M.; Parenti, D.M.; Squires, L.E.; Williams, R.; Castel, A.D.; et al. Sexually Transmitted Infections Among HIV-Infected Individuals in the District of Columbia and Estimated HIV Transmission Risk: Data From the DC Cohort. Open Forum. Infect Dis. 2018, 5, ofy017. [CrossRef] 
6. Hughes, G.; Field, N. The epidemiology of sexually transmitted infections in the UK: Impact of behavior, services and interventions. Future Microbiol. 2015, 10, 35-51. [CrossRef]

7. Unprotected Nation The Financial and Economic Impacts of Restricted Contraceptive and Sexual Health Services. SSHA. 2013. Available online: https:/ / ssha.info/unprotected-nation-the-financial-and-economic-impacts-of-restricted-contraceptive-andsexual-health-services/ (accessed on 6 January 2022).

8. Newman, L.; Rowley, J.; Vander Hoorn, S.; Wijesooriya, N.S.; Unemo, M.; Low, N.; Stevens, G.; Gottlieb, S.; Kiarie, J.; Temmerman, M. Global Estimates of the Prevalence and Incidence of Four Curable Sexually Transmitted Infections in 2012 Based on Systematic Review and Global Reporting. PLoS ONE 2015, 10, e0143304. [CrossRef]

9. Lewis, D.A. HIV/sexually transmitted infection epidemiology, management and control in the IUSTI Africa region: Focus on sub-Saharan Africa. Sex Transm. Infect. 2011, 87, ii10-ii13. [CrossRef]

10. Fatusi, A.; Wang, W. Multiple sexual partnership mediates the association between early sexual debut and sexually transmitted infection among adolescent and young adult males in Nigeria. Eur. J. Contracept. Reprod. Health Care 2009, 14, 134-143. [CrossRef]

11. Sigbeku, O.A.; Fawole, O.I.; Ogunniyan, T.B. Experience of intimate partner violence as a predictor of sexually transmitted infections among married women in Nigeria. Ann. Ib. Postgrad. Med. 2015, 13, 6-16.

12. Ogbe, A.E.; Sagay, A.S.; Imade, G.E.; Musa, J.; Pam, V.C.; Egah, D.; Onwuliri, V.; Short, R. Declining prevalence of Hiv and other sexually transmitted infections among female sex workers in Jos, North-Central Nigeria. Afr. J. Med. Med. Sci. 2014, 43, 5-13.

13. Ahoyo, A.B.; Alary, M.; Méda, H.; Ndour, M.; Batona, G.; Bitéra, R.; Adjoni, C.; Medegan, V.K.; Labbé, A.C.; Adjimon, T. Female sex workers in Benin, 2002. Behavioural survey and HIV and other STI screening. Sante Montrouge Fr. 2007, 17, $143-151$.

14. Federal Ministry of Health Nigeria. Integrated Biological and Behavioural Surveillance Survey; Federal Ministry of Health: Abuja, Nigeria. Available online: https:/ /naca.gov.ng/wp-content/uploads/2016/11/Final-Nigeria-IBBSS-2014-report.pdf (accessed on 6 January 2022).

15. New Survey Results Indicate That Nigeria Has an HIV Prevalence of $1.4 \%$ I UNAIDS. Available online: https: / /www.unaids.org/ en/resources/presscentre/pressreleaseandstatementarchive/2019/march/20190314_nigeria (accessed on 6 January 2022).

16. HIV and AIDS in Nigeria. Avert. 2015. Available online: https://www.avert.org/professionals/hiv-around-world/sub-saharanafrica/nigeria (accessed on 1 February 2022).

17. Mayaud, P.; Mabey, D. Approaches to the control of sexually transmitted infections in developing countries: Old problems and modern challenges. Sex. Transm. Infect. 2004, 80, 174-182. [CrossRef]

18. James, P.B.; Wardle, J.; Steel, A.; Adams, J. Traditional, complementary and alternative medicine use in Sub-Saharan Africa: A systematic review. BMJ Glob. Health 2018, 3, e000895. [CrossRef] [PubMed]

19. Nuwaha, F.; Muganzi, E. Predictors of use of traditional medicine by patients with sexually transmitted infections in southwest Uganda. J. Altern. Complement. Med. 2008, 14, 733-739. [CrossRef]

20. Mmari, K.N.; Oseni, O.; Fatusi, A.O. STI Treatment-Seeking Behaviors Among Youth in Nigeria: Are There Gender Differences? Int. Perspect. Sex. Reprod. Health 2010, 36, 072-079. [CrossRef]

21. Peltzer, K. Utilization and Practice of Traditional/Complementary/Alternative Medicine (TM/CAM) in South Africa. Afr J Tradit Complement Altern Med 2009, 6, 175-185.

22. World Health Organization. Global Health Sector Strategy on Sexually Transmitted Infections, 2016-2021. 2016. Available online: https://www.who.int/reproductivehealth/publications/rtis/ghss-stis/en/ (accessed on 6 January 2022).

23. Garrett, N.J.; McGrath, N.; Mindel, A. Advancing STI Care in Low/Middle-Income Countries: Has STI Syndromic Management Reached Its Use-by Date? Sex. Transm. Infect. 2017, 93, 4-5. [CrossRef]

24. Romero, C.P.; Marinho, D.S.; Castro, R.; de Aguiar Pereira, C.C.; Silva, E.; Caetano, R.; Elias, F.T.; Chilcott, J.; Dixon, S. CostEffectiveness Analysis of Point-of-Care Rapid Testing Versus Laboratory-Based Testing for Antenatal Screening of Syphilis in Brazil. Value Health Reg. Issues 2020, 23, 61-69. [CrossRef]

25. Nwadike, V.U.; Olusanya, O.; Anaedobe, G.C.; Kalu, I.; Ojide, K.C. Patterns of sexually transmitted infections in patients presenting in special treatment clinic in Ibadan south western Nigeria. Pan Afr. Med. J. 2015, 21. [CrossRef]

26. Oharume, I.M. Knowledge, sexual behaviours and risk perception of sexually transmitted infections among students of the polytechnic, Ibadan, Oyo state. Afr. Health Sci. 2020, 20, 39-44. [CrossRef]

27. Akokuwebe, M.M.E. Knowledge and attitude of sexually transmitted diseases among adolescents in Ikeji-Arakeji, Osun State, in South-Western Nigeria. Afr. J. Med. Med. Sci. 2016, 45, 281-289.

28. Archibong, M.A. Perceptions about Sexually Transmitted Diseases in Akwa Ibom State of Nigeria: A Qualitative Study of Young Adults Age 18-24. Ph.D. Thesis, Walden University, Minneapolis, MN, USA, 2016. Available online: https://scholarworks. waldenu.edu /cgi/viewcontent.cgi?article=3620\&context=dissertations (accessed on 6 January 2022).

29. Nwabueze, S.A.; Azuike, E.C.; Ezenyeaku, C.A.; Aniagboso, C.C.; Azuike, E.D.; Iloghalu, I.C.; Ebulue, C.C.; Epundu, U.U.; Nwone, O.F. Perception of Sexually Transmitted Infection-Preventive Measures among Senior Secondary School Students in Nnewi-North Local Government Area, Anambra State, Nigeria. Open J. Prev. Med. 2014, 4, 708. [CrossRef]

30. National Institute of Health. HIV and Opportunistic Infections, Coinfections, and Conditions:-HIV and Sexually Transmitted Diseases (STDs). Available online: https://hivinfo.nih.gov/understanding-hiv/fact-sheets/hiv-and-sexually-transmitteddiseases-stds (accessed on 6 January 2022).

31. National Population Commission (NPC) [Nigeria] and ICF. Nigeria Demographic and Health Survey 2018. 2019. Available online: https://www.dhsprogram.com/pubs/pdf/FR359/FR359.pdf (accessed on 24 October 2020). 
32. Amu, E.O.; Adegun, P.T. Awareness and Knowledge of Sexually Transmitted Infections among Secondary School Adolescents in Ado Ekiti, South Western Nigeria. J. Sex. Transm. Dis. 2015, 2015, 260126. [CrossRef] [PubMed]

33. Ikimalo, J.; Obunge, O.K.; Babatunde, S.; Ikokwu-Wonodi, C.; Briggs, N.D.; Kemp, J.; Dollimore, N.; Brabin, L.; Agbaje, O.; Hart, C.A. Sexually transmitted infections among Nigerian adolescent schoolgirls. Sex. Transm. Infect. 1999, 75, 121. [PubMed]

34. Brabin, L.; Kemp, J.; Dollimore, N.; Obunge, O.K.; Ikimalo, J.; Briggs, N.D.; Odu, N.N.; Hart, C.A. Reproductive tract infections and abortion among adolescent girls in rural Nigeria. Lancet 1995, 345, 300-304. [CrossRef]

35. University of Benin (Nigeria). Wikipedia. 2021. Available online: https://en.wikipedia.org/w/index.php?title=University_of_ Benin_(Nigeria)\&oldid=1059800300 (accessed on 30 December 2021).

36. Cochran, W.G. Sampling Techniques, 3rd ed. Available online: https://www.wiley.com/en-us/Sampling+Techniques\%2C+3rd+ Edition-p-9780471162407 (accessed on 11 November 2021).

37. Federal Ministry of Health Nigeria. National HIV/AIDS and Reproductive Health Survey I Health and Education Resource Centre., November, 2013 (NARHS Plus II, 2012). 2013. Available online: https:/ / healtheducationresources.unesco.org/library/ documents/national-hivaids-and-reproductive-health-survey (accessed on 11 November 2021).

38. Akinsoji, A.A.; Olufunmilola, A.A.; Idowu, A.A.; Pius, A.O. Sexual and Contraceptive Practices among Female Undergraduates in a Nigerian Tertiary Institution. Ethiop. J. Health Sci. 2015, 25, 209-216. [CrossRef]

39. Cadmus, E.; Owoaje, E. Knowledge about complications and practice of abortion among female undergraduates in the University of Ibadan, Nigeria. Ann. Ib. Postgrad. Med. 2011, 9, 19-23. [CrossRef]

40. Isiugo-Abanihe, U.C.; Erinosho, O.; Ushie, B.; Aderinto, A.; Sunmola, G.; Joseph, R. Age of Sexual Debut and Patterns of Sexual Behaviour in Two Local Government Areas in Southern Nigeria. Afr. J. Reprod. Health 2012, 16, 81-94.

41. Takele, A.; Setegn, T. Sexual Coercion and Associated Factors among Female Students of Madawalabu University, Southeast Ethiopia. Adv. Public Health 2014, 2014, 417517. [CrossRef]

42. Gravelin, C.R.; Biernat, M.; Bucher, C.E. Blaming the Victim of Acquaintance Rape: Individual, Situational, and Sociocultural Factors. Front. Psychol. 2019, 9, 2422. [CrossRef]

43. Jewkes, R.; Morrell, R.; Hearn, J.; Lundqvist, E.; Blackbeard, D.; Lindegger, G.; Quayle, M.; Sikweyiya, Y.; Gottzén, L. Hegemonic masculinity: Combining theory and practice in gender interventions. Cult. Health Sex. 2015, 17, 96-111. [CrossRef]

44. Okafor, K.C.; Adam, V.Y.; Azuike, E.C. Sexual practices and factors affecting sexual outcome of young people in Oluku community, Ovia North East Local Government Area, Edo State, Nigeria. Glob. J. Med. Public Health 2018, 7, 1. Available online: https://www.academia.edu/43047879/Sexual_practices_and_factors_affecting_sexual_outcome_of_young_people_ in_Oluku_community_Ovia_North_East_Local_Government_Area_Edo_State_Nigeria (accessed on 30 December 2021).

45. Obiajuru, O.C.; Jude, N.O. The Prevalence of Sexually Transmitted Infections among Post-Primary and Tertiary School Students in Imo State, Nigeria. Niger. J. Health Biomed. Sci. 2007, 6, 90-95. [CrossRef]

46. Femi-Adebayo, T.T.; Kuyinu, Y.; Adejumo, O.A.; Goodman, O. Factors affecting utilization of youth friendly health services in Lagos State, Nigeria. Int. J. Adolesc. Med. Health 2017, 31, 1-7. [CrossRef] [PubMed]

47. Sekoni, A.O.; Odukoya, O.O.; Onajole, A.T.; Odeyemi, K.A. Sexually Transmitted Infections: Prevalence, Knowledge and Treatment Practices among Female Sex Workers in a Cosmopolitan City in Nigeria. Afr. J. Reprod. Health 2013, 17, 94-102. [PubMed] 